\title{
On Computers and Men
}

Tomasz Goban-Klas

University of Information Technology

and Management in Rzeszow,

Sucharskiego 2 Street,

35-225 Rzeszow, Poland

e-mail: tgoban@wsiz.rzeszow.pl

\begin{abstract}
:
The title of the article was inspired by the novel by John Steinbeck "Of Mice and Men" (1937) and the poem by Robet Burns about the deception of human plans. Even the best of them often lead astray, or their far-reaching negative effects are revealed. As it seems, nowadays nature ("mice") and men (people) are in a breakthrough period - in the geological sense between the old and the new era, the Holocene and the Anthropocene, in the cultural sense - between the analogue and digital era that can be - and it should actually be called a digit. Levi-Strauss in his essay "Raw and cooked" points to the groundbreaking for the emergence of human culture the use of fire in the preparation of food, and therefore the transition from nature to culture, and its foundation - the kitchen [12]. At present, this new phase of transition can be seen in the digitization of interpersonal communication and its current correlation - crosslinking. It was announced by the famous Turing machine (1936), a computer design and layout, which was realized in the 1940s and 1950s, and enter in mass production at its end, networked on a global scale in the 1990s and make mobile in the second decade of the 21 st century in the form of a smartphone Keywords: Turing machine, computer, anthropocene, digital plenitude.
\end{abstract}

To a Mouse,

But Mouse, you are not alone, In proving foresight may be vain: The best laid schemes of mice and men

Go often askew, And leave us nothing but grief and pain, 
The title of the article was inspired by the novel by John Steinbeck "Of Mice and Men" (1937) and the poem by Robert Burns about the deception of human plans. Even the best of them often lead astray, or their far-reaching negative effects are revealed. As it seems, nowadays nature ("mice") and men (people) are in a breakthrough period - in the geological sense between the old and the new era, the Holocene and the Anthropocene, in the cultural sense - between the analogue and digital era that can be - and it should actually be called a digit. Levi-Strauss in his essay "Raw and cooked" points to the groundbreaking for the emergence of human culture the use of fire in the preparation of food, and therefore the transition from nature to culture, and its foundation - the kitchen [12]. At present, this new phase of transition can be seen in the digitization of interpersonal communication and its current correlation - cross-linking. It was announced by the famous Turing machine (1936), a computer design and layout, which was realized in the 1940s and 1950s, and enter in mass production at its end, networked on a global scale in the 1990s and make mobile in the second decade of the 21 st century in the form of a smartphone.

These achievements of human thought - technical and logical - introduced into common human practice change the traditional - seemingly old practices of the analogue era bring them into digital and network forms. More and more extensiveness and strengthening of human capabilities through the media, and new digital tools, including the so-called artificial intelligence, AI. The realization of a vision about which some philosophers and theologians dreamed of, like Theiard de Chardin, is beginning to approximate. Its concise reminder and indication of the basis for its implementation is contained in this article.

\section{Noosphere - a New Sphere of Our World}

For over a dozen years, seeing the enormous impact of human activity on the global ecosystem, some of them have recognized that humanity has entered a new geological epoch - the Anthropocene. The term was proposed by Paul Crutzen, Nobel laureate. The authors of the "Anthropocene Review" argue that the beginning of the Anthropocene era should be considered half of the twentieth century.

In the Anthropocene - if we accept this distinction of this new geological-biological era the material and energetic scale of human activity plays a key role, but after all directed - as homo socialis et comunicans - by human culture and through inflows and flows of information into the social system and human minds. Therefore, its component is not only the geosphere, biosphere and technosphere (material and energetic artificial basis of functioning of societies), but also the sphere of culture, called the noosphere for centuries.

The Russian scholar Vladimir I. Vernadsky [9], author of an important work "Biosphera" (1926), believed that in the development of the Earth, just as the appearance of life fundamentally changed the geosphere, so - according to Vernadsky - the emergence of people endowed with cognitive abilities will completely transform the biosphere (these views do not were widely accepted in the West) [10]. He completed this developmental line indicating that after the geosphere (inanimate matter) and biosphere (biological life), the noosphere as the "cloak of the mental Earth," the set of all information and their media on the planet, is its third component

It becomes obvious that the biggest change in human life - individual and social - is in the sphere of ways and means of communication, and - after Jay D. Bolter [10] - it can be expressed in two words: ubiquity and diverstity. The first one emphasizes the widespread (global) availability of computers of all kinds, including multimedia mobile phones, the second that mediamorphosis maintains and even increases the diversity of media devices, not reducing them to one universal transmission tool. 
It develops - using the term of the pope Benedict XVI - continento digitale, a digital continent, based on a network, also wireless, and therefore ubiquitous or all-extending [11]. Thus, the noosphere has a material basis - the media apparatus - the space flow of Manuel Castells is real and palpable. Information flows through it, created not only by people, but also by apparatus, processed not so much by human minds but by algorithms. It becomes a key element of management, management, all activity of machines and people. Castells used the term "informationalism," it can be included in the concept of media civilization and define and analyze it as an information and media civilization [3].

After the Second World War, the computer became - as Bolter pointed out - the so-called technology that defines modernity, both realistically and metaphorically ("the Computer Age") introducing humanity into the information society. In his book "Turing's man. Western culture in the computer era" [2], he describes the internal operation and structure of the computer (time, space, language and program) in contrast to old technologies, optically and physically simpler (reel, potter's wheel, clock, steam engine), which today shape the mind of the user and society in its image and likeness. This is an essentially optimistic analysis - "Turing's man" is an expert in their machine and its limitations, wisely and ethically using it.

If you look for a ground-breaking intellectual announcement of the anti era it could be found in the article by Alan Turing from 1936, proposing a scheme of operation on the symbols later called the "Turing machine." The article "On Computable Numbers" or "About computable numbers" described an abstract machine that was able to perform a programmed mathematical operation, i.e. algorithm. In 12 years later, in 1948, in the paper "A Mathematical Theory of Communication," Claude Shannon announced the invention of a transistor, the basis of computerization and digitization [13].

Bolter develops an interesting comparison of the main - dominant - technologies and their metaphors from antiquity to modern times. For the ancient Greeks, according to Bolter, the dominating technological metaphor was a drip spindle, a device for twisting yarn in a thread. Such a metaphor implied technology as a controlled application of power. In Western Europe, after the Middle Ages, the analog to the spindle was first a clock with a load, the triumph of mechanical technology, and then a steam engine, the climax of the dynamics of thermal energy. In the subtly developed observation of Bolter, a computer - as a metaphor defining the present age - is a machine that connects the conceptual ideas of both the clock and the steam engine. However, paradoxically, the computer also represents a return to antiquity in the sense of a certain image of the manual world.

In several well-thought-out chapters on how the computer redefines our concepts of space, time, memory, logic, language and creativity, Bolter makes a comparison in which the computer simultaneously introduces a new wonderful Western technology and turns us back to the idea of ancient Greece. He states that "if the ancient ideals were balanced, proportional and craft (using the spindle), and Western European was Faust's pursuit of power through knowledge (understanding the mechanical universe to achieve the dynamics of the steam engine)," Turing man "combines both ideals" [2, p. 323].

"In a way, a computer man keeps and even extends the Faustian tendency to analyze," concludes Bolter. "But remember, he adds, that the purpose of Faust's analysis was to understand, and this" in-depth, problem, while Turing's man is oriented not so much at understanding, at acting" [2, p.334].

"For a Turing man, knowledge is a process, a skill," just like ancient pottery art. "A man or computer only knows something if it can get the right answer to the right question." Speaking more informative language when an algorithm is prepared. "Faustian depth" adds nothing to the operational success of the program. 
Thus portraying the "Turing man," Bolter seems to refer to the use of a few simple metaphors. However, he develops his arguments with unusual concreteness. If there is any weakness in them, it is included in the range in which he presented a too repetitive and ultimately predictable pattern of computer operation.

Bolter claims that "the computer is the latest and most radical defining technology because it has become the dominant metaphor of the human mind in popular culture as well as in more technical fields such as psychology and neuroscience. This metaphor is essentially a Turing man." Bolter claims that Alan Turing was right when he predicted that computers would be able to imitate human intelligence perfectly, but "because the machine thinks like a human being, man recreates himself, describes himself as a machine ... as information processor and nature as information for processing." Trying to build artificial intelligence, we have transformed into artificially intelligent creatures, that explains Bolter's position.

However, much more important in the "Turing's man" is to fill the gap between the exact sciences and the humanities. After reading Bolter's book, the reader finds that the computer is much less mysterious than he thought. It is not a coincidence that the book allows us to understand why computers are not so perfect in mathematics (for example, they cannot use the concept of infinity); but they are helpful in explaining the "Turing test" for assessing artificial intelligence.

The most provocative in the analysis is what Bolter has to say about the political consequences of computer age. Will Turing's man prove the power of George Orwell's "Big Brother" instruments as so many observers are afraid of widespread surveillance? It's very possible that he did not, said Bolter in 1984: “... computer age cannot really produce people who are capable of great good or evil." Turing's man is not a possessed soul, as often as a Faustian is, he does not treat himself and his world so deadly seriously, he does not talk about "destiny," but if the computer age does not produce Michelangelo and Goethe, it is probably less likely to produce Hitler or even Napoleon. Totalitarian leaders were people capable of concentrating the Faustian commitment of the will of citizens to their goals. And what if they lack their strong will? Orwell's "1984" assumption was to combine a totalitarian goal with modern technology. "But the most modern technology, computer technology, may be incompatible with a totalitarian monster, at least in its classic form," probably Bolter wrote too optimistically .

\section{Computer in the 21st Century - the Same (Turing's Machine), But Not the Same!}

After all, 35 years have passed since the writing of "Turing's Man," which was very inspiring and still today, and although the logical diagram of the computer has not changed at that time, the computer itself has changed technologically (and programmatically). It is the same, but not the same. And new technology has given him new possibilities (affordance) and creates a new, wonderful and less-than-perfect digital real-life (according to Manuel Castells [3]).

This is perfectly understood by professor Bolter. He in 2019 published a monograph on Western culture in the computer era, titled "Digital Plenitude," or digital abundance, even excess. excess [1]. Its key idea is to say that our media culture is full of excess. This is the world of products (websites, video games, blogs, books, movies, TV and radio programs, magazines, etc.) and practices (creating all these products together with their remixing, sharing and commenting), is therefore vast, diverse and dynamic which is not understood and understood as a whole. "Excess easily adapts, even absorbs, contradicts the forces of high and popular culture, old and new media, conservative and radical social views. Digital media are an ideal environment for this fullness - for our flattened media culture, in which there are many central points, but there is no single center."

Yuval Noah Harari in the book "21 lessons for the 21st century" looks even further: "We live in an age when people are hacking. Algorithms are looking at you at this moment. / ... / Based 
on big data and machine learning, they will get to know you better. And when these algorithms will know you better than you, then they will be able to control you and manipulate you, and you will not be able to do anything about it" [5, p. 342].

Pedro Domingos in his book "The Master Algorithm: How the Quest for the Ultimate Learning Machine Will Remake Our World" is describing as algorithmic machine learning is remaking business, entertainment, politics, science and military. And he gives a description of the quest to find 'The Master Algorithm' - a universal computer-based learner capable of deriving all knowledge from data. It would be a radical, or better say, total transformation of way as human knowledge is transformed into data, and then, into human life. This vision is not fully optimistic, it contains the seed of terrifying future - full control of humans by machines. In October 2015, a software called "AlphaGo®" became the first computer to beat a professional human Go player in game of Go, more difficult them the chess. It is a clear sign that the Artificial Intelligence mature and is going to master other than games fields of human inventness.

A century and a half ago Karl Marx and Frederic Engels published the "Communist Manifesto" announcing that "A Spectre is haunting Europe - the spectre of Communism." Today, we read more and more philosophical manifestos are warning about perils of artificial intelligence. By 2014, the famous scientist and philosopher Stephen Hawking and business magnate Elon Musk had publicly voiced the opinion that superhuman artificial intelligence could provide incalculable benefits, but also can end the human race if deployed incautiously. One may say: "A new spectre is haunting the world - the Spectre of the Universal Master Algorithm," or - expressing more cautiously - the Spectre of the Algocracy. From masters, humans may become slaves. And that it would be an end of Turing's Man.

\section{References}

1. Bolter, J. D. The Digital Plenitude: The Decline of Elite Culture and the Rise of New Media, Cambridge: The MIT Press, 2019.

2. Bolter, J. D. Człowiek Turinga. Kultura Zachodu w erze komputera, trans. by T. Goban-Klas, Warszawa: PiW, 1991.

3. Castells, M. Społeczeństwo sieci, trans. by M. Marody et al., Warszawa: PWN, 2008.

4. Domingos, P. The Master Algorithm: How the Quest for the Ultimate Learning Machine Will Remake Our World, New York: Basic Books, 2015.

5. Harrari, Y. N. 21 Lessons for the 21st Century, New York: Spiegel \& Grau, 2018.

6. Bolter, J. D. Examining and Changing a World of Media,

http://leading-edge.iac.gatech.edu/humanistic-perspectives/examining-and-changing-a-world-ofmedia./

7. http://movies2.nytimes.com/books/99/01/03/specials/bolter-turing.html.

8._Vernadsky, V. https://www.geochemsoc.org/files/4813/4436/8118/gn125.pdf.

9. Wiernadski, W. https://pl.wikipedia.org/wiki/W\%C5\%82adimir_Wiernadski.

10. Bolter, J. D. https://www.digitalplenitude.net/.

11. Laskowska, M., Marcyñski, K. Komunikacja społeczna wedtug Benedykta XVI, Kraków: Petrus, 2016.

12. Lévi-Strauss, C. Surowe i gotowane, trans. by M. Falski, Warszawa: Wydawnictwo Aletheia, 2010

13. Shannon, C. A Mathematical Theory of Communication, The Bell System Technical Journal 27, 1948, pp. 379-423, 623-656. 